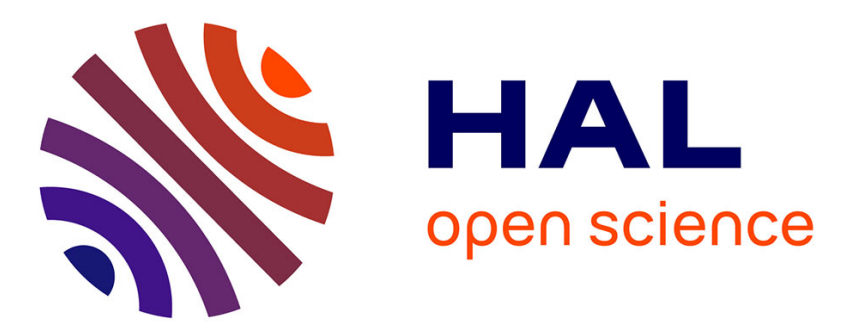

\title{
European identity and European citizenship in three "Eurocities": A sociological approach to the European Union
}

\author{
Adrian Favell
}

\section{- To cite this version:}

Adrian Favell. European identity and European citizenship in three "Eurocities": A sociological approach to the European Union. Politique européenne, 2010, 1 (30), pp.187-224. 10.3917/poeu.030.0187 . hal-01023809

\section{HAL Id: hal-01023809 \\ https://hal-sciencespo.archives-ouvertes.fr/hal-01023809}

Submitted on 15 Jul 2014

HAL is a multi-disciplinary open access archive for the deposit and dissemination of scientific research documents, whether they are published or not. The documents may come from teaching and research institutions in France or abroad, or from public or private research centers.
L'archive ouverte pluridisciplinaire HAL, est destinée au dépôt et à la diffusion de documents scientifiques de niveau recherche, publiés ou non, émanant des établissements d'enseignement et de recherche français ou étrangers, des laboratoires publics ou privés.

\section{(ㅇ)(1) 80}

Distributed under a Creative Commons Attribution - NonCommercial - ShareAlikel 4.0 


\title{
EUROPEAN IDENTITY AND EUROPEAN CITIZENSHIP IN THREE "EUROCITIES" : A SOCIOLOGICAL APPROACH TO THE EUROPEAN UNION
}

\author{
Adrian Favell \\ L'Harmattan | Politique européenne
}

$2010 / 1-n^{\circ} 30$

pages 187 à 224

ISSN 1623-6297

Article disponible en ligne à l'adresse:

http://www.cairn.info/revue-politique-europeenne-2010-1-page-187.htm

Pour citer cet article :

Favell Adrian, « European identity and european citizenship in three "eurocities" : a sociological approach to the European Union »,

Politique européenne, 2010/1 n³0, p. 187-224.

Distribution électronique Cairn.info pour L'Harmattan.

(C) L'Harmattan. Tous droits réservés pour tous pays.

La reproduction ou représentation de cet article, notamment par photocopie, n'est autorisée que dans les limites des conditions générales d'utilisation du site ou, le cas échéant, des conditions générales de la licence souscrite par votre établissement. Toute autre reproduction ou représentation, en tout ou partie, sous quelque forme et de quelque manière que ce soit, est interdite sauf accord préalable et écrit de l'éditeur, en dehors des cas prévus par la législation en vigueur en France. II est précisé que son stockage dans une base de données est également interdit. 
Adrian FaVELL

\section{EUROPEAN IDENTITY AND EUROPEAN CITIZENSHIP IN THREE “EUROCITIES": A SOCIOLOGICAL APPROACH TO THE EUROPEAN UNION}

This text is a complement to the book Eurostars and Eurocities in which the practices and sentiments of those who might be considered archtypal new Europeans are analysed - that is, the views of the ultra-mobile Europeans who have moved to live and work and work in another member state of the EU. The research is based on 60 interviews with residents of three of the major hubs of European mobilty: the "Eurocities" of Amsterdam, London and Brussels. Focusing on those who moved, most often because of a desire to get away from the restrictive circumstances they felt in their own home country, the article analyses the opinions of these individuals about Europe. It shows the low consistency of their attitudes towards the EU, which contrasts with their intense usage of the new possibilities that the EU offers its citizens. This however is not the case concerning the political rights guaranteed by the Maastrict Treaty. Eurostars rarely vote in the cities where they live, and if they are interesteed in politics, for the majority it is politics in their home country. It is in their daily life, as consumers, neighbours, public service users and cultural entrepreneurs that they exercise their European citizenship. This is also how they legitimate the European project, rather than in developing a so-called "European identity". The findings thus end by questioning arguments concerning the notorious "democratic deficit" of the EU.

\section{Identité et citoyenneté européennes dans trois "Eurocités». Une approche sociologique de l'Union Européenne.}

Ce texte complète le livre Eurostars and Eurocities dans lequel sont analysées les pratiques et les sentiments de ceux qu'on peut considérer comme l'archétype des nouveaux Européens, à savoir, les Européens mobiles partis s'installer dans un autre pays de l'UE. La recherche repose notamment sur soixante entretiens avec des résidents des trois points centraux de la mobilité européenne que sont les trois "Eurocités": Amsterdam, Londres et Bruxelles. L'article analyse les opinions sur l'Europe de ceux qui sont partis, le plus souvent dans le désir d'échapper au cadre étroit de leur nation d'origine. Il montre la faible consistance des attitudes des

politique européenne, $\mathrm{n}^{\circ} 30,2010$, p. 187-224. 
Eurostars à l'égard de l'UE, qui contraste avec la réalité de l'usage intensif qui est le leur des possibilités nouvelles qu'elle offre à ses citoyens. Sauf pour ce qui touche aux droits politiques ouverts par le Traité de Maastricht: les Eurostars ne votent pas dans les villes où ils sont installés, et sìls sintéressent à la politique, c'est pour la majorité d'entre eux celle de leur pays d'origine. C'est dans leur vie quotidienne, en tant que consommateurs, voisins, usagers des services publics locaux et entrepreneurs culturels qu'ils exercent leur citoyenneté européenne. C'est ainsi qu'ils légitiment le projet européen, plutôt qu'en développant une soi-disant "identité européenne ", mettant ainsi en question le fameux "déficit démocratique " de l'Union européenne.

THE INVENTION of European citizenship has created a range of extraordinary economic and political rights for foreign citizens, that might arguably be considered the world's first example of fully institutionalised trans - or post - national political rights beyond the nationstate. ${ }^{1}$ Yet despite an avalanche of theoretical and normative reflection on the potentialities of European citizenship, and a growing body of quantitative research on European identity linked to official sources of data such as Eurobarometer, there has been relatively little grounded sociological work on the political participation of European citizens. To advance this question, I here present material from an unpublished chapter of my book Eurostars and Eurocities: Free Movement and Mobility in an Integrating Europe (Favell, 2008), as well as data from an accompanying quantitative survey, Pioneers of European Integration (Recchi and Favell, 2009). I offer new evidence about the usage of European citizenship rights by individuals who might be considered amongst the most highly Europeanised of EU citizens.

Eurostars and Eurocities is an ethnographic and documentary study of the experiences of foreign European citizens living and working in three of the EU's major hubs of internal mobility: Amsterdam, London and Brussels. A total of 60 lengthy personal interviews with individuals and couples were conducted in the early 2000s in the three cities. These are the people who might be considered prototypical European citizens. They are the very image of the European Commission's highest ideals

\footnotetext{
${ }^{1}$ I would like to thank the editors of the journal and this special edition, as well as the anonymous referees for advice and suggestions on this paper. Thanks also to Ian Manners who gave a very helpful close reading of the text at an earlier stage in its development.
} 
of free movement, having exercised their European right to move internationally and build a life and career in another member state. The qualitative study was supplemented by a cross-national network based quantitative survey, the PIONEUR project (Pioneers of European Integration), which interviewed 5000 European citizens from the five (then) largest EU member states living as foreigners in the five largest member states (i.e., France, Germany, Italy, Spain, U.K.). ${ }^{2}$

As this article first shows, it is not hard to find these ideal type Europeans expressing a kind of European identity as a way of making sense of their life and work choices and mobility. However, as we explore their attitudes and (especially) behaviour more closely, these Eurostars are also perplexingly apathetic about the exercising of European citizenship rights to participate formally in local and European elections in their country of residence. This varies across the cities, and according to the political issues faced locally.

Theories of European citizenship and surveys of European identity often flatten and misrepresent the experience and significance of European freedom of movement. To get beyond the clichés, it is essential to listen to the voices of European citizens; to understand the nuances of their political attitudes, as well as the impact of different city contexts. As well as stressing the comparison across the three cities, I bookend the article with the transcript of an interview also not included among Eurostars and Eurocities many in situ "tales". This form of presentation also follows the style of the book, where each analytical chapter is followed by an interview that reflects back on the discussion, but also deepens and extends it. The interview here, with the wellknown Brussels activist and politician Rik Jellema, thus offers a story which puts flesh and blood on many of the political enjeux raised by the life and experiences of European free movement, as well as an acute analysis of the political scenario faced by foreign European residents in the city of Brussels. Part of my method is to suggest that a fully contextualised, everyday account of political participation such as this is needed to grasp what is really wrong (and right) with European citizenship. We

\footnotetext{
2 "Pioneers of European Integration 'from below': Mobility and the Emergence of European Identity among National and Foreign Citizens in the EU", Framework V project (2003-6), directed by Ettore Recchi, University of Florence. See our website: http://www.obets.ua.es/pioneur.
} 
should not forget that the true experts on this subject are the European citizens themselves, whose voices are so rarely heard in political science research. ${ }^{3}$

\section{Road to nowhere}

Viewed sociologically, European integration can be understood as essentially driven by mobility across borders (a view first established by Deutsch et al 1957; reprised by Rodriguez-Posé 2002, Fligstein 2008). The canonical freedom of movement of goods, capital, services and persons thus enshrines and facilitates the building of Europe via an essentially negative integration logic (Scharpf, 1999). By breaking down borders to free movement of all kinds, the patterns of mobility, exchange and interaction between Europeans are to be de-nationalised, hence robbed of the bounded territorial container that has always made the nation-state the pre-eminent economic, social and political unit of society in modern Europe. Not least, the removal of borders aimed at tempering the exclusive nation building dynamics that made inter-state rivalries over the last three centuries the most potent source of war in the continent. Viewed this way, the Europe that is emerging can be defined, not as a nation or state in the making, but rather as an undefined space of expansive freedom and mobility, as much as of peaceful trade and exchange. Insofar as this space is a reality it is so because people have used these opportunities to do new things across national borders: go shopping for cheaper petrol or wine; buy property in charming rustic villages; look for work in a cosmopolitan foreign city; move to retire in the sun; take holidays in new destinations; buy cheaper airline tickets; plan international rail travel; join cross-national associations between twinned towns; use a common currency without having 5\% "commission" stolen by a bank - and a thousand other actions facilitated by the European free movement accords (on such European citizenship "practices", see also Wiener 1998).

${ }^{3}$ One of the obvious inspirations for this approach is Bourdieu et al (1993), particularly the practice of publishing transcripts of interviews in full. While I do not subscribe to the activist methodology of that work - which tended to put words and ideas in the mouths of respondents - the attempt to present the situated voices in vivo is a vital idea in the sociological approach I propose here. See note 5 infra for a reference to other methodological choices made in this research. 
All of this may well be proceeding fine without yet the need for people to be stopped to ask about how they feel about it. Yet somewhere during 1990s, the European institutions became fairly obsessed with the need to define te EUmore positively as an entity itself providing selfconscious "identity" - as an explicitly alternative entity to nation-state identification. They had always been nagged by the sense that someone ought to take seriously Jean Monnet's oft-quoted, but little substantiated, comment that European integration should have begun with culture not economy. As the new millennium approached, a threatening rhetoric emerged at national levels about the EU's so called "democratic deficit", and its alleged emotional disconnect with its citizens (see, for example, Siedentop 2000). In response, the EU institutions began to vigorously promote publicity and policies designed to build consciousness of Europe among its national citizens (Shore, 2000; Forêt 2008).

One consequence was that a lucrative research industry on "European identity" emerged, mostly on the back of the regular Eurobarometer: a questionnaire that charts on an annual basis how popular the EU is today, what they feel about nations, markets or immigrants on a 1-10 scale, whether they would buy an EU constitution with their cornflakes in the morning - and other such questions apparently crucial to the functioning of a modern democracy (archetypal Eurobarometer research on European identity includes: Gabel, 1998; Citrin and Sides, 2004; Green, 2007; Fligstein, 2008, ch.5; on problems with Eurobarometer, see Bréchon and Cautrès, 1997; for alternative methodologies see Duchesne and Frognier, 2002; Díez Medrano, 2003, Bruter, 2005; for overviews, see Herrmann, Risse et al, 2004; Checkel and Katzenstein, 2009). Figures about identification with the EU fluctuate wildly, and are notoriously variable across member states. In most recent times, the worry has turned to near desperation, as European elections produce ever more dismal results, and the clapometer of public opinion shows declining appeal for the EU, even as its citizens exploit ever more vigorously the free moving travel, shopping, retirement and career opportunities that would not exist without it. ${ }^{4}$

\footnotetext{
${ }^{4}$ Euroscepticism may appear rife in other measures, but when asked about European citizenship in terms of rights, $37 \%$ of European citizens think they would be willing to move to another country that offered better conditions, 53\% think the "freedom to travel and work in the EU" is the most important single benefit of membership - ahead of the Euro ( 44 per cent) and peace (36 per cent) - and 57\% have travelled internationally within the EU in the last two years (source: Eurobarometer 64:1, 2005).
} 
Low turnouts at European elections, and the growing anti-EU sentiments everywhere following the crushing rejection by core members of the EU constitution in 2005, and record scores for Eurosceptic parties in 2009, only seemed to confirm the chorus of anti-EU feeling across the continent lambasting the European construction. People just do not want to identify with the work of all those bureaucrats in the offices in Brussels, even if they are more than happy to reap the benefits of their efforts. One might describe this as an "attitude problem".

Europe's identity problem is, however, in large part a problem with the notion of "identity" itself, with which commentators, scholars, politicians and journalists, have increasingly wanted to frame the issue (see Brubaker and Cooper, 2000; Favell, 2005). For them, staging the debate in the reductive "hardball" (i.e., highly Americanised) logic of two dimensional, either/or politics, European identity is consistently set up as a rival for the European nation-state, for or against: either to be cheered along as a radical post-national alternative, or (more likely) damned in the name of patriotic nationalism and nation-state exceptionalism. But, as the blatant disjunction between feelings about Europe and exploitation of rights show, the problem may lie with conceiving of integration, not behaviourally - in terms of what people are doing, the kinds of social patterns that have emerged and developed as a result of freedom of movement - but attitudinally, in terms of a normative projection of social-psychological change.

The European Union's big mistake was to try to market the many supplementary individual rights of free movement offered to nationals of the member states - what became packaged for PR purposes after Maastricht as "European citizenship" (Maas, 2007) - as a genuine form of citizenship. They thus engaged in a dangerous game of rhetoric in relation to this core notion at the heart of the modern nation-state and its emotive allegiances. For what else might European citizenship be except something that transcends and perhaps replaces national citizenship? Scholars played their part, overlaying the debate with grandiose cosmopolitan illusions of a post-national European state and polity, in which EU citizens would gradually learn to leave behind their historical national affiliations (i.e., most famously, Habermas, 1992; Beck and Grande, 2004; see especially the research agenda pursued by researchers at ARENA, Oslo in this vein, i.e., Eriksen, 2005). But notions of European citizenship suggest a fully formed democratic nation-state on 
the model of classic modern national democracies: a European Union seen in this light can only be judged as fatally flawed in terms of political identification. Hence, we arrive at the "democratic deficit", judging the European construction as if it were a historical European nation-state -society, a rhetorical gift to eurosceptics everywhere across the continent (see again Siedentop 2000; and a response in Moravscic, 2002).

On the other side, this has not deterred those who dream of a European citizenship. The EU institutions may as yet have failed to convincingly construct a European population in its own image. But with its multiple arms of university funding in Europe, the US, and further afield, they have been spectacularly successful in constructing a European community of EU scholars, hooked on the pre-packaged Euro-data and Euro-agenda the institutions produce. Since Meehan's pioneering work (1993), a great deal of academic effort has thus been spent in the last two decades by theorists specifying the counterfactual conditions for the development of a "true" European citizenship. European citizenship scholars offer a variety of perspectives, but what links notable name in these debates (i.e., Weiler, 1998; Magnette, 1999; Kostakopoulou, 2001; Bellamy and Castiglione, 2006; Shaw, 2007) is a concern with debating the normative philosophical potentials of European citizenship, rather than a focus on evidence about actual participation.

For sure, one of the key rights that EU free movers enjoy is the right to vote in both local and European elections in their chosen country of residence. This is indeed one of the most obvious political dimensions of the notion of European citizenship, and the element that links the participatory rights of EU citizens as political actors, with their economic and social rights as consumers and wage earners in a free Europeanised common market. Against this backdrop, it is reasonable to expect that the movers are people who might be considered among the most "highly Europeanised citizens" of the EU - the kind of people who might be thought to care most about their putative European citizenship - and that therefore they are a crucial test case for European citizenship. We know the notion often inspires idealistic prescriptions about political participation, rights and democracy beyond the nation-state, but how is it actually experienced and practiced? Both my study and the PIONEUR project offer findings on this subject. 
One of the key arguments of previous European identity studies has been to suggest that there is in fact nothing incompatible between national identities and European identities (Risse 2004). Regarding the special case of free movers, then, PIONEUR generated an interesting series of results that suggested in fact that the most plausible sociopsychological role for a European identity is to assist in cognitive dissonance reduction: providing individuals a means to find a midway between their otherwise incompatible national and regional identities, and allowing them to feel comfortable with both (Rother and Nebe, 2009).

Translated into political attitudes, it is thus not hard to find textbook examples of good Europeans in this sense among my own interviewees. ${ }^{5}$ David, a successful self-employed management consultant in Amsterdam, is an archetype, an English expat, at home as a European every bit as much as he is integrated into Amsterdam life, yet recognisant of his original national identity. The combination is simply the way he lives his life and conducts his business: the European Union thus makes perfect sense for him. He describes himself as a strong supporter of the EU and "felt very moved when we got the Euro". Saskia in the City of London is a high flying risk assessment specialist from Belgium, who looked first to America for her career, before realising that Europe's quality of life and welfare benefits mattered more to her. She also repeats the kind of argument that the European Commission would dearly love its citizens to adopt. For her, the EU is a supplement to national identity, and a practical necessity for Europe. As a Belgian in the US, she started to feel more European, emphasising the feeling that Belgium has always to be thought of as part of a "larger entity".

But both Saskia, and Franz, a banker in London, affirm a version of European identity that is at odds with the PIONEUR findings about cognitive dissonance. Instead, they are the acme of Europe as the promise of what is referred to in Eurostars and Eurocities as a "de-nationalised" kind of individualism. Europe enables them to move away from their national identifications, and live a more individualistic life. Other interviewees point to how their awareness of "being European" relates

\footnotetext{
5 For extensive details about the range of interviews, the personal backgrounds of interviewees, the sampling methodology in each city, and the interview strategies used, see appendices 1 and 2 of Eurostars and Eurocities, pp.232-239. Names of interviewees quoted here are given pseudonyms and blurred identities, with the exception of Rik Jellema, who is a well-known Brussels politician.
} 
to the concrete benefits of not being discriminated vis-à-vis national residents, something they feel is in stark contrast to the treatment of non-European, non-white immigrants. There is also link made in people's minds with emergent regional and city based identifications; being European has also become a broader and more inclusive identification after the Mediterranean, Scandinavian and East-Central European enlargements.

There are different points of view articulated according to context, though. To Belgians in the Netherlands, free movement rights are not linked in their mind to the EU - but to the longer standing customs union within Benelux countries. One or two of my Eurostars also express versions of Euroscepticism, particularly about the loss of diversity that Europeanisation seems to entail. This is most likely in London, where a couple of residents have internalised English Euroscepticism as a proud mark of their successful integration into life in the capital. Some aspects of the European construction do seem to echo the worries most visibly expressed in the French and Dutch constitutional vote that European integration is a cover for homogenising global capitalist interests. Valérie, a French resident in London, who works in the City as a broker, has a strongly held view on this question. It is worth lingering awhile to listen to how she expresses these feelings:

"I understand the arguments [about the benefits of the EU], but [like the English] I also don't want the Euro. What I think is a shame, is that I've seen during my recent travels [around Europe] that there is more and more uniformity. There's no more individuality. It's really remarkable. You find the same programmes here, in France, in Germany, in Italy. Where is the individual character of each country? OK, the Euro is good for having the same money, but each country I think is going to lose its identity. It's not all a good thing. I don't see what the interest is in everything resembling each other. I don't like to be the same as others. It's for that that I'm here, and so I understand the English attitude, especially since they have their own island. It would be sad to lose that, this culture, when there is already so much uniformalisation."

She blames the EU for processes that appear - as she then points out - to be more to do with globalisation - and the capitalist interests for which she works. As is often the case, the inconsistencies in her behaviour, get rationalised in terms of the socio-psychological babble of "identity". 
"When I arrived here, I felt more Italian than French [she is a French national of Italian family origin]. I don't always recognise myself with French people. I have certain Italian things about my values, the family, in relation to how I was educated, and it makes sense because my grandparents came to France but raised their children in an Italian way, and so did my parents. So I don't feel I'm anything. I'm Valerie, voilà."

Notably then, it is her "de-nationalised" state that she stresses the most. Yet she doesn't reduce the dissonance here by turning to a European identity, which I suggest might be a solution for some people:

"Well it might be a belle idée, but... We're all different, that has to be appreciated. So, no, I don't feel myself to be European..."

Take the question back towards practicalities, though, particularly the specific regional economies of scale that the European Union offers, and the benefits seem more distinct. A businessman can see these issues in a particularly clear way. Dave, who now runs his own courier business in Brussels after several years working in Amsterdam, has been amazed at the bureaucratic differences between even neighbours as close as Belgium and the Netherlands. He sees the introduction of the Euro in positive terms, because it will make business across borders far more transparent. People shopping around for the best deals - including internationally - will help this work efficiently.

Claudia and Miguel, an Italo-Portuguese couple in Brussels, summarise the point well. Eurostars can take the benefits of European mobility - economic and otherwise - but would rather be cautious about more grandiose academic talk of "identity". When I ask them about their attitudes to Europe, I point out that they themselves as married, and having studied and worked together in a foreign European country, they are a great example of European integration:

Claudia - "Yes, that's very good. That's a thing I would accept voluntarily. It's a good experience [to have moved]. It's great to have benefited from the European space, but..."

Miguel- "I agree in the idea of a European Union. We try to have a European life. We feel European. But I think that it's overblown political rhetoric [démagogie politique] of others to talk about a 'European identity'. There will always be national sentiments. I think that's a real failure [of the EU]. We can hope again with the Euro. There will be a little impetus, in that we are all concerned." 
The sociological point here can be pressed further in theoretical terms. Behaviour is so much more fundamental than attitudes; this surely is the EU's best hope. The fundamental unit of society is not an opinion or a belief; it is an action or interaction. Of course, you can ask people the "identity" question - how do you feel about the EU, does "being European" now come in third, fourth or fifth behind your national identity, regional belonging, favourite football team, or preferred brand of training shoe (and other modern identities that we slip in and out of)? - but the blunt truth is that this extra question is quite simply redundant once you have good behavioural data, that tells you what people actually do in an integrating Europe. Political scientists inevitably think first of voting and the "revealed preferences" they supposedly denote, but "being European" nowadays is as much likely to be about this, as it is about all the manifold things that people can now do more easily across borders. These ways of being European - that can all be counted, or interrogated for meaning - are notably also enjoyed by many who overtly profess themselves to be Eurosceptic or to have no European identity at all.

Such action may well be spatially as well as socially structured. Certain research for example, has affirmed that spatial factors (i.e., residence near a border), is linked via experience to positive attitudes on the EU (Gabel, 1998; Berezin and Medrano, 2008). This confirms the older tale that historians such as Hartmut Kaelble (1989) have told about European integration being driven by a regional core, traceable in the regionallyminded urban populations along the central spine of Western Europe, as much as the leading pro-European politicians who came from these parts (see also Therborn,1995, ch.10). In other words, the psychological superstructure - what people think of, and retrospectively rationalise, when asked, as their "identity" - rests on behavioural foundations, that actually might prove to be very material and interests-driven to begin with.

Talk of European identity, then, largely obstructs what we should be studying. But what of European citizenship, conceived in behavioural terms? European residents have the right to vote in local and European election, and surely a strong, self-conscious motivation to participate in their chosen place of residence as Europeans. Have they been exercising their European citizenship - as surely they must, according to the theorists - in voting and electoral participation? It is a far from straightforward question, as the following evidence shows. 


\section{Don't worry about the government}

The general evidence for the participation of EU citizens to date in both local and European elections has always suggested it is low. Broad systematic studies, such as the cross-national study of the implementation of European citizens rights by Strudel $(2002,2003)$, and a study over time of EU citizens participation in Brussels by Bousetta and Swyngedouw (1999), both discovered surprisingly low rates of participation - as well as many institutionalised barriers - among a population who would have thought to be prototypically "highly Europeanised" in their attitudes. This lack of participation - particularly in Brussels where so many of the target voters are involved (in their employment) in the European project - is perplexing and calls for further investigation.

PIONEUR furnishes us with some general evidence on the political orientation of European free movers. Compared with European Social Survey (ESS) findings about the average EU population (the "stayers"), EU movers are more interested in politics (being more highly educated), yet considerably less participative; they are half as likely to have participated in their last home country elections; and they are less likely to be politicised on a series of other measurements of politicisation (on these and other findings, see Muxel 2009). Taking the classic left/right cleavage questions on two dimensions, the survey reveals that the population tends to combine a more left wing attitude to state intervention on social policies and the welfare state, ${ }^{6}$ with a more open liberal attitude to moral/cultural questions. ${ }^{7}$ That a certain anti-free market attitude on the economy is relatively common is perhaps ironic given the $\mathrm{EU}$ is usually perceived as a "neo-liberal" project on the continent. However, findings on the economic question were mixed. Regarding the total of $40 \%$ of EU movers who position themselves on the left (which compares to between $25 \%-33 \%$ of Europeans as a whole, and to $22 \%$ of EU movers who say they are on the right), more than half were hostile to economic liberalism, while about a quarter accepted it. These two left-wing affiliations then tended to have distinct social profiles, as seen in Table 1. Those against economic liberalism tend to be younger (39\%

\footnotetext{
$644 \%$ disagreed with the statement: "The less the state intervenes in the economy the better it is for the country."

$748 \%$ agreed strongly with the statement: "Gay men and lesbians should be free to live their own lives as they wish."
} 
of those under 40 , versus only $23 \%$ for), and they have higher than average professional levels ( $46 \%$ of those against belong to the service class, compared to $41 \%$ of those for), yet there are more men (58\%) than women among the free market left, and their level of education is slightly lower than those in favour of state intervention $(50 \%$ have a university degree versus $57 \%$ of those against economic liberalism).

TABLE 1: Break down of "left-wing” attitudes among EU movers (\%)

\begin{tabular}{|l|c|c|c|c|c|c|}
\hline & Men & $\begin{array}{c}<40 \\
\text { years }\end{array}$ & $\begin{array}{c}\text { Service } \\
\text { Class }\end{array}$ & $\begin{array}{c}\text { University } \\
\text { degree }\end{array}$ & $\begin{array}{c}\text { Young } \\
\text { migrants } \\
\text { short stay }\end{array}$ & $\begin{array}{c}\text { High level } \\
\text { of } \\
\text { politicisation }\end{array}$ \\
\hline $\begin{array}{l}\text { Left-wing anti } \\
\text { free market }\end{array}$ & 49 & 39 & 46 & 57 & 35 & 31 \\
\hline $\begin{array}{l}\text { Left-wing pro } \\
\text { free market }\end{array}$ & 58 & 23 & 41 & 50 & 21 & 21 \\
\hline Indifferent & 44 & 37 & 42 & 48 & 32 & 18 \\
\hline Total of sample & $\mathbf{4 9}$ & $\mathbf{3 1}$ & $\mathbf{3 8}$ & $\mathbf{4 4}$ & $\mathbf{2 7}$ & $\mathbf{1 7}$ \\
\hline
\end{tabular}

Source: PIONEUR project.

Overall, though, the political profile matches fairly well the general political orientation of the European Commission and the institutions, which is liberal on both social and economic scales in European terms. Among my population of Eurostars, as well as many that embody this kind of profile, there are also a number of respondents who buck the trend that might suggest Euro-cosmopolitanism is an exclusively leftwing thing. Axel in Amsterdam, a successful manager in a telecommunications multinational in Amsterdam, and Claudia and Miguel in Brussels, as well as several business entrepreneurs and corporate high flyers I talked with, exemplify the strong free market, anti-state, antitaxation orientation of some Eurostars. The political profile of interviewees also underlines the broadly middle class (rather than "elite" background) of most movers.

A section of my interviews focused on asking individual citizens about their awareness and motivations to participate in local elections, exercising their voting rights as prototypical "European citizens". Where 
relevant I also discussed participation in European elections, and their interest in national elections in both their host and origin countries. On the face of it, as residents, some of them long term, it would seem likely that they would be particularly motivated to vote on local issues that materially affect them, whether it is local issues of quality of life, traffic, environment, development, street cleaning, cycle lanes, or whatever.

But is this the case? What exactly is at stake in this question? As we will see below, Rik Jellema's view as a politician suggests many reasons why these residents should have a serious political interest in the quality of life issues (on the environment, transport, local governance, and so on) that emerge in their everyday life in the city - many of which are indeed the exact reasons why (again, for "quality of life" reasons) many of these movers have chosen to live and work abroad in these foreign cities. Despite their ambiguous connections to the host countries, and their clearly individualistic, mobile view of life, there is a serious question - raised by entrepreneurial political characters such as Jellemaabout how to mobilise their considerable economic, human and social capital collectively on the local stage to effect change. Given the intensity of typical domestic middle class urban struggles - over issues such as gentrification or access to schooling (Butler and Robson, 2003; Andreotti and Le Galès, 2010) - these foreign middle classes ought to be a powerful emergent group in city politics. These sixty or so individuals are highly international, cosmopolitan, often very pro-European, and distinctly self-styled urban professionals. A large majority of them are strongly involved in the social, cultural and economic life of their chosen city of residence. Many of them strongly self-identify as "Londoners", "Bruxellois/Brusselaars", or "Amsterdammers". What is noticeable, however, across all the cities, is how this involvement almost never translates into political participation as such. The ideals of European citizenship seem way off in their hopes that this might be an effective route towards Europeanisation and a more democratic Europe.

When asked about this Nicole, a young French woman in London, shrugged in a way typical of nearly all interviewees - who would otherwise be classified among some of the most politically and culturally aware members of the European population. She says she was lazy and didn't go looking for information, when they didn't sent it. She says she reads newspapers, follows politics, but is much more interested in her 
home country politically. She knows she is not going to stay for long. Some interviewees are even surprised by the question. For example, Valerio, an Italian who has been living and working in the Netherlands for several years, thinks he is not able to vote, and ignored invitations to vote at the city level. "I'm living as if this was part of Italy", he laughs.

Several other movers said they had wanted to vote, but didn't - for trivial reasons, such as absence on the day or failing to get organised in time. Their casualness betrays the lack of significance the vote has; or, at least, that the rhythm and shape of their life does not match too well with the requirements of a normal citizen. Conceptually, in political terms these mobile Europeans see themselves as still fundamentally linked to where they come from, or to a broader European entity, even if most other aspects of their lives are in the foreign city. This may signal a different kind of spatial awareness - a way of living that is not the conventionally nationalised one of the native resident at home - rather than apathy or apolitical attitudes. In conversation with Dominic, a French broker in London, he points to issues he feels are important at the local level - and yet why local participation still makes no sense, and how France remains his main political reference point. When I ask him if he follows French politics, he responds as if this is a truly stupid question: of course, he does. Donatella, who has been living and working in the City several years says something similar: politics, for her means Italy, and she still follows developments avidly. Or Franz and Carmen in London. Franz has just been stressing how German identity means little or nothing to him now. They are also home owners, with a strong interest in their neighbourhood, strong opinions on life in England, and strong self-identification as European citizens. Yet they have only ever voted in their home countries - and still do.

It is not just a question of temporary attachment. Stefan is one of the most perplexing cases. He is a successful young architect, with an internationally renowned Dutch office. He has been living outside of Germany for nearly all his adult life. Highly integrated in Amsterdam life, a house owner with an Australian wife and child who speaks Dutch, he is very motivated in getting involved in all aspects of local urban life, and talks animatedly about local schools, his neighbourhood, city housing policies, and urban planning. He is a committed Amsterdammer in so many ways - yet it turns out he sees his political commitment, not in the city he lives in, but totally in Germany. This pattern is common, even for the most politically engaged and aware. Tom, in Brussels, is 
Irish, a committed trades unionist, working for the international association. I ask him if he voted in the local elections in Brussels.

"No. We were a bit guilty. I thought, especially working where I do, I shall have to remain anonymous! Yeah, I would be interested [in participating]. I read quite a bit about it when I saw some expats were standing in some areas, and the resistance to it... [Laughs] I'm on dodgy grounds here. You know, theorising about it in the pub, but then not doing anything about it."

Of course, a few of the interviewees are the prototypical "barbarians" (Angell 2001): international free movers, concerned only with escaping the binds or obligations of any nation-state, with only cynicism about politics. For instance, Miguel and Claudia, the Portuguese-Italian couple, now homeowners and working in Brussels. The conversation might come as a shock to idealists of European citizenship:

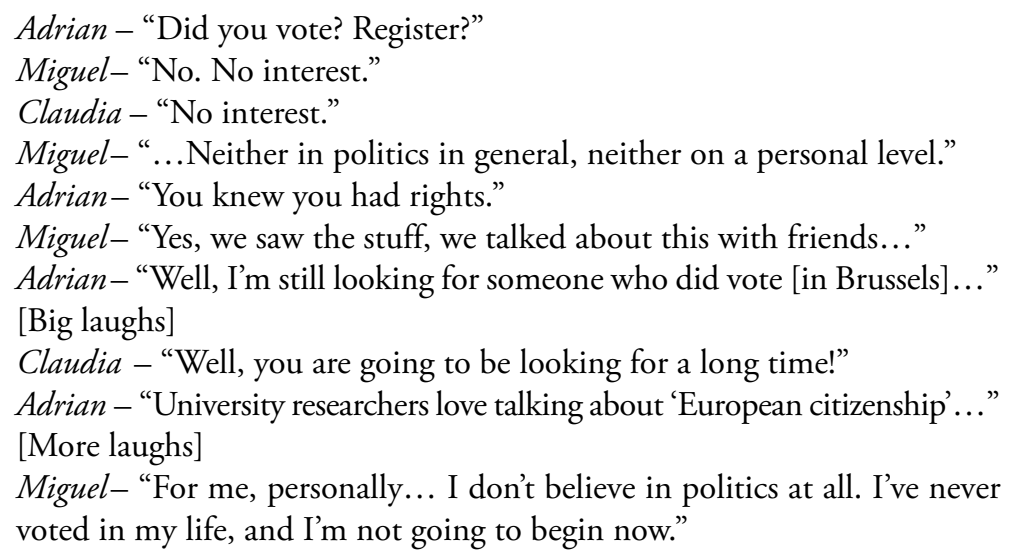

The only thing that gets this group going politically is taxation, a notorious problem in Belgium for the self-employed. It's the one thing that makes them want to leave - barbarians, of course, always vote with their feet. Ray, an independent businessman in Amsterdam, also expresses this kind of view. He says he has never voted, and thinks it wouldn't make any difference "wherever". His "respect" for politicians would be the same anywhere. This is the classic barbarian point of view, but it is striking that from his other testimony, Ray is obviously an internet news junky, is very concerned about his economic contribution to Dutch society, and is strongly committed to bringing his children up there. As we move up into the high flying world of corporate finance lawyers in the Netherlands - some of the most self-styled free movers in 
my sample - the message is crystal clear. Nina and Maria dismiss my questions, telling me you can read the newspaper if you are interested, but that Dutch politics had no relevance at all "for me".

It might not be too much to have subtitled this section: the apathetic, the apolitical and the downright cynical. Not exactly the kind of European citizens theorists have in mind when they construct their normative models of political participation and democracy.

\section{Life during wartime}

Of course, this general picture needs qualifying across the three cities. A minority of interviewees had exercised their political rights as European citizens, and there were some interesting differences between the modalities of politics in each of the three cities, that led to different types and likelihood of participation. The trick here is to try to specify the mechanisms by which it succeeds or (more likely) fails, particularly in relation to the resident ethnic minority populations, and the irony of their often more convincing political inclusion in the city - despite their disadvantage in almost every other respect.

\section{London}

Of the three cities, post-national non-participation was at its highest in London. The scale and free market driven individualism of London perhaps accounts for the far less present involvement of local government issues in the details of everyday life. On the other hand, there are plenty of issues to get foreign European residents riled up. For example, Sandra, a long term Luxemburgher resident, living in affluent Kensington. She feels rather settled in London, and is well integrated. I ask her if she has voted in local elections. Her response begins like so many others - no, she hasn't - before veering off into a rant about how much she hates the mayor (at that time) Ken Livingstone, the congestion charge, the lousy underground system, and the lack of sensible bicycle lanes. Like many she feels London's "quality of life" is terrible, but she is not going to vote in order to do anything about it.

The one or two people that did vote, did so less out of political commitment, more out of a sense of curiosity, or because it was fun. Rainer, the mid-career manager with Unilever, was not going to miss the 
chance to vote. He loves having these rights - so he can talk with the candidates when they come to the door campaigning. He laughs, though, that they were "a little bit turned off by my accent". When they did vote, some interviewees were not even sure which election they voted in. Valérie, from France, also found it funny, doing it with a pencil and putting a cross. They didn't verify her identity, and was amazed at the levels of trust about potential fraud that would never be the case in France. I also uncovered one or two cases of Britain's famously loose electoral registration practices, actual leading to national election voting cards being sent out to foreign residents. This perhaps was not what the architects of European citizenship had in mind. In conversation with an older Spanish couple, who had been living in England three or four years, I asked if they had voted as European citizens? They had a funny story.

Carlos- "For the local council, not the European.."

Susana - "No no! It was for the general election... I did!"

Carlos- "Voting here is a folklore kind of exercise. We didn't know much about it."

Susana - "I wanted to see what it was like, so I voted. It was not for the local election, it was for the general election. That's something that shocked me. In Spain, when you vote, they check your identity card, and then you get a tick, and you have voted and you cannot vote again. I went to the police station with a letter sent by them [voting registration card] with my name and address. As they don't have id here, they asked me, 'Are you Susana Hernandez?', and I said, 'Yes.' 'OK, you can vote..' It could have been my neighbour... Or my mother [laughs].”

Norbert, a young German resident, did vote, but again with a rather voyeuristic motive: he'd never voted in his life, and just wanted to try it. He'd filled in the registration card, and showed up to vote. He says he pays his council tax, and has some general ideas about democracy and participation, but that he is not really interested in the local elections. He even knows some Japanese friends who were able to vote because the council didn't check ids. But in the end, Norbert also admits that what really counts for him is German politics. 
Brussels

What about European Citizenship in the political capital of Europe? Here, foreign European residents have well publicised local voting rights, although they are not located at the level of the region - a point of regret and political significance, as Rik Jellema points out in the interview - but rather at the highly localised, yet politically important commune level elections, every six years. Uniquely among European cities, the high percentage of European residents, coupled with their concentration in certain communes such as Ixelles, in fact creates the possibility of a serious electoral impact of this population on Belgian politics as a whole (Bousetta and Swyngedouw, 1999). In particular, it is of vital importance as regards the precarious balance of Walloon versus Flemish interests in the city, on which European votes could make a big difference. Although both sides tend to assume residents will naturally side with the francophones, in fact it would only take more than $15 \%$ of the foreign Europeans to side with the Flemish to alter the balance in their favour $-15 \%$ being the very approximate size of the Dutch speaking population in Brussels, on which political calculations on representation are based. Also, Brussels is a leader in multicultural participation after the big local successes of Moroccan, Turkish and African representation at the city level (Jacobs, 2000).

Participation in Brussels thus offers a natural setting for exploring the reality of European citizenship. After all, this is a highly euro-conscious population, many of whom work in close contact with the European institutions and European politics orbiting them. If there is no real sense of emerging European citizenship here, then where in Europe could there be? Yet despite huge efforts by the Region, by communes, by Belgian political parties on both sides of the linguistic divide, by the Brussels-Europe Liaison office, and by the widely read local magazine for expats Bulletin, very few resident Europeans bother to register or vote in local elections. Why not? All were aware of their rights; many felt uncomfortable that they had not got involved; most were "political" animals by nature. For example, almost all of my interviewees admitted to not having voted or even register in the 2000 local elections. Overall less than $10 \%$ of the foreign European population registered for that election, and a majority of these were longer term working class foreign residents, not the Eurostars. EU citizen participation in Brussels is, it 
turns out, the dog that doesn't bark - even if, as IT consultant Gunther insists I point out somewhere in my "report", there are still far too many dogs that are allowed to "shit on the street".

Gunther himself didn't vote. Although resident in Brussels, he cannot register properly because of tax reasons connected to his business. Alternately, he got involved in the governance of his children's school. Bent, a management consultant who is also a local landlord, and Siobhan, an IT start-up manager, are both motivated enough, and have real local issues to raise. Again, perplexingly, it does not translate into political action. Siobhan believes you should get involved, but she sees no way into the associational life of Belgians. I point out that Belgians put a big accent on local participation, and tend to be very active in associations and so on. She is, in fact, turned off by how everything is so political in Belgium, where you "have to play the game" to understand "the way it works here". All this is despite the efforts of the Belgian political parties, as well as local communes and the region, to mobilise such residents.

Belgian political parties had however made some attempt to woo these voters given the fragile linguistic balance of Dutch speaking versus Francophone representation in certain communes. Parties were able to obtain classified lists of registered voters, which signalled if they were foreign residents or not. Sometimes this backfires. This is something pointed out to me by a Dutch journalist friend, Kees. Over a late night beer at the Ultime Atome café one evening we talk about Belgian politics. Kees has very much wanted to participate in the election, but couldn't because it turned out he had to organise a traditional "bull frog" party that day back with old friends in Den Haag. He had grown up partly in Brussels, so was very much at home working for an international organisation in the city. Here was a Brussels European citizen highly motivated to vote - but on the Dutch speaking side. He was one of many Dutch, German, Nordic and English speakers who belied the common perception that foreign European residents automatically side with the French speakers in the city. These nationalities in Brussels together total significantly more than the $15 \%$ it would take to affect the current balance. In fact, he was infuriated that in Ukkle, where they lived, he was automatically assigned to the French speaking political lists, as a European resident, even though he was Dutch. He was also annoyed that parties had complete access to foreigner status list and 
addresses, which meant he had been the target of some campaigning. In the end, it was the rigidity of the Belgian system of voting that put him off. Not being sure if he could be physically present on the day (as is required), and knowing that there are fines for not voting in Belgium, he was one of the $90 \%$ or so European residents who didn't register. Kees was so angry about the whole issue he sent back his electoral card as a protest.

Others were very much aware that they might be awkward bureaucratic consequences from registering to vote, in situations where their interest in influencing the local political issues was marginal and they couldn't be sure to be in town on the right day. Bernhard is highly motivated politically, and also sides with the Flemish in Brussels. But again, he didn't vote for this simple trivial reason. Janet, meanwhile, a PR manager working for Unilever corporation in the city, found out the hard way the costs of being a committed European citizen and actually registering. Let us listen to her story.

"I got my fingers burned last September, when I enrolled to vote in the European elections. I've been living here for five years and I thought: 'I should exercise my right to vote'. I've been paying taxes very high here -although you shouldn't necessarily link taxes and voting together - so I registered. Because I was in the 'right' age group, I got called in with two days notice to do voting duty. If you are between 30 and 32 , you are the age group they ask, you are the most intelligent or most flexible, or whatever. So I have to turn up in Kraainem [a controversial commune à facilités], and sit the whole day from 7.30am to 4.30am, ticking off names on a list, for 20 Euros compensation! I was very very pissed off. If I didn't do it, I'd get a 600 Euros fine, according to the leaflet I got... All the Belgians really dodge things. They say, 'Oh, my 83 year old granny is coming', or 'I've got an airline ticket'. My Belgian boss said to me, 'Oh, you should have said to me, we could have sent you off on business somewhere'. But I was too honest, played it by the rules... It was very frustrating, it really put me off Belgian politics. There's no way I'm getting involved again, forget it."

Although she had to help supervise voting for the national election taking place at the same time, she was of course not allowed to vote in it. At least she can see the funny side.

"I had a bit of a laugh. [Because of the rules], I had to speak and write for the people in Flemish, which I don't speak! 'Goede daag, meeneer, kommen binnen' [in a terrible Dutch accent]. They are looking at me, and they are like, "What was that??" 
Again, despite being politically aware, even idealistic, Janet found that European citizenship didn't mean much to her. I asked if there were issues that mobilised her.

"Not really. I wouldn't know how to get involved. To me, it's a minefield. The parties are not appealing. I wouldn't know who to approach in Ixelles... I voted for Agalev [Flemish green party], the year before. I voted for a guy because he was called Costello, like 'Elvis Costello'. He was with Agalev or the Green party, I can't remember. I thought, 'That sounds like a nice name.".

Much of the problem in Belgium comes down to the fact that the internal Belgian political struggles don't mean a lot to foreign European residents, and don't represent issues close to their interests or ideas. Dario, a successful architect, is one of the most settled and engaged long term residents I meet in Brussels. He is thoroughly aware of the issues, but he still admits that it is Italy - a country he has not lived in for over 10 years - where he feels politically rooted. The problem is that Dario in fact feels alienated by the shape and terms of politics in Belgium. It is not at all that he lacks political interest or opinions. But the cleavages that appeal to his political sensitivities are found better in his native country. He, like others, is also out off by the extremes of Belgian politics, such as the rise of the openly racist Vlaams Blok (now Vlaams Belang). When the most engaged foreign residents still feel this way about the local political scene, it is perhaps not so surprising that they choose not to participate directly in party politics in their adopted city. They do not perceive that the elections would make much difference to the kinds of issues that might matter to them at the local level: such as the troublesome rubbish collection, local security and policing, housing developments, lack of cycle lanes, dog shit, parking problems, and so on. These clearly are issues that could motivate all residents - Belgian or not. But it appears that the Belgian parties are often much more concerned with local culture and language issues, and only view foreigners as stylised "expats" which no such concerns.

The mobilisation gap became clear when I went to visit, on invitation, the elected responsible for foreign residents in Ixelles, Julie de Groote. Unfortunately, at the last minute the meeting was cancelled and I was passed off on to two of her junior assistants, both rather geeky, fresh-faced Walloons straight out of university, who did their best to answer my questions. It was immediately clear that there was little 
awareness in the commune, of who the large European population are, or what they might want - despite being $28 \%$ of the electorate in the commune.

Francophone complacency is matched by Flemish defensiveness and negativity about foreigners in the city. Yet Flemish parties are clearly missing an opportunity in not seeing that many North Europeans would align with them. A small political event which exemplified this was the success of the Flemish green party, Agalev, in targeting and mobilising Euro voters in the Brussels-City commune in the 2000 elections, as mentioned above by Rik Jellema. They focused on this affluent, young group of gentrifiers, promoting questions of environment, amenities and culture in the inner city. The strategy worked. A handful of extra votes led to an electoral breakthrough and their elected representative, Bruno de Witte, going on to become alderman. Given the mathematics of minority representation in the city, he then became the pivotal Flemish representative within the new ruling left-green coalition.

For sure, the apparent lack of formal local public participation of European residents in voting - but also in housing associations, self-help groups, local committees and the like - has to be seen as a disappointment. It is not that these residents shun participation in other ways in the city. Many of them, too, are highly political animals. Their lack of participation - which stands in deep contrast to the growing participation and electoral successes of other immigrant populations in the city - perhaps can be explained by something other than apathy or ignorance. As Ingrid points out, a veteran Danish resident in her 60s who is about to retire from the Commission after 25 years there, Belgium is arguably the most difficult country in western Europe to understand politically, given its multiple levels and cleavages. Belgian politics is also already an extremely "full" space, with parties and personalities crammed into all the different local levels of activism. Europeans are not excluded from this, but it is difficult to push into the political agenda issues that have nothing at all to do with the typical Belgian obsession with Flemish-Francophone struggle and manoeuvring, or the new, emerging agenda of multicultural immigrant politics in Brussels. To some degree their political efforts may be expended in their politicking and networking within exclusively EU and international centred issues. Furthermore, with a relatively high quality of life and degree of contentment, they feel no great pressure to get involved for social change 
as such. Many of the structures set up by the Brussels Region and the EU institutions to facilitate participation, in fact deal with their problems in ways that deflect them from political engagement. Liaison committees and information packs are addressed to the concerns of temporary or newly arrived residents, rather than committed Bruxellois/Brusselaars. Eurostars are thus much more likely to express their political opinions through their activism as consumers, and the kinds of choices they make about their lifestyles and culture in the city. On this score, their political impact has been considerable.

Perhaps then there is a need to step away from the kind of idealist conception of European citizenship, by which these individuals participation in Brussels or Belgian life will always rated as proof of "apathy" or "non-integration". They are obviously not hampered economically or culturally in the city as consumers. Maybe it is as consumers, therefore, that their political impact should be evaluated. Voting is more or less irrelevant in the context of intense Belgian political debate that is not in any significant way addressed to them. Yet in their dynamic occupation as gentrifiers of various neighbourhoods, in their extensive use of services, and in their sympathy for progressive and cosmopolitan trends in the city, they have expressed themselves in a way far more significantly than turning out to vote in communal elections.

\section{Amsterdam}

Political participation poses the same kind of obstacles in Amsterdam where, as in Belgium, a bewildering array of parties, with often minor or very specific ideological differences, cluster around the voters' choices. Of the three cities, Amsterdam is by far and away the most difficult to settle in and integrate in the long run as a foreigner. However, among the minority of people who have managed to integrate effectively in the city, there is a more overt commitment to political participation, particularly in the many local ballot initiatives that are raised for dealing with local issues - referenda on public transport (the north-south underground line, for example), new urban developments (building in the Ijmeer), or city level environment and governance issues.

As in London or Brussels, the shape of national Dutch politics does not appeal. One English resident, Alan, a self-styled "alien" businessman, expressed the usual jaded feeling with normal politics - which, in fact, 
expresses the same sentiments that lie behind much of the Dutch electorate turning to new alternatives, such as the openly racist Lijst Pim Fortuyn or Geert Wilders, in recent years. He says there are "so many parties that they can't organise it that one party has a majority, so they spend so much time talking about things that nothing gets done". Others, such as Helen, an Irish logistics manager or Marlena, a Belgian journalist, echo the problem voiced in Belgium, that the shape of Dutch politics does not speak to them.

However, participation begins to make much more sense when it is framed in terms of common urbanistic interests that are not defined by the typical national party political cleavages. David, the well integrated management consultant, is still wary of being thought of as naturalised Dutch, but he is $100 \%$ a committed Amsterdammer. He always votes in local elections, and is "motivated in local issues that affect me personally". He cites boats going up and down the canals outside the house, and the problem with squatters. He began to organise his neighbours to do something about it, talked to local politicians and someone he knew in television to get the squatters out. In a sense, this is really what local citizenship is all about: not ideology, not party politics, but local conflicts over everyday living. David's apparent NIMBYism here in fact, is indicative of his very high degree of commitment to his locality. He is concerned about protecting the "quality of life" in his neighbourhood, linked especially to his involvement in the local gay scene. He voted for a candidate who was canvassing to turn a local street with gay bars into a pedestrian street. But he is not bothered about larger "national" issues such as education or health. For David, Amsterdam is home, and uniquely welcoming to his lifestyle. Yet Britain still retains more political emotion for him.

Other long term residents echo his terms of local participation. Sophie, a French research scientist thought it was "a chance" to be allowed to participate, and had been motivated by the same issues as her Dutch neighbours. One significant difference in the Netherlands is that long term non-European resident foreigners can also often get a vote at local level. Local politics then generally has more meaning for foreigners - of all kinds. Guillaume is also French, and is actively involved as a gay activist and as a campaigner for immigrant rights. His anger with much of what he has seen locally in the Netherlands on immigration issues has led him to first get involved, and eventually become a foreign candidate in local elections. 
David, Sophie and Guillaume, at least, have found mechanisms of participation that make sense for them, and speak to their situation as long term resident foreigners in the country.

\section{Conclusion: Nothing (But Flowers)}

Is the weak evidence of political participation among the Eurostars all just more grounds for Eurogloom and doom? Not necessarily. Politics is about ultimately "social power" (Mann, 1993), not just formal political participation. In terms of their actual influence in their chosen cities, and the de facto modes of participation of resident European citizens, there are many grounds for thinking that the practical exercising of everyday mobility rights - outside of voting and party politics - is indeed legitimising the "post-national" European project. It is driven by their fulfilment of the notion of freedom of movement, and their nonpolitical party focused form of urban participation - as consumers, cultural entrepreneurs, and gentrifiers in the cities. Mobile European citizens might appear a particularly apolitical group in conventional political terms, but their high level of engagement in other ways in their chosen cities might also be seen as an urban form of the "new politics" that have characterised much participation in the post-ideological era of the last two decades (Savage et al, 2005). The material impact of these residents is most apparent in Brussels - where their numbers are greatest and where they are strongly concentrated in parts of the city - even if formal rates of participation remain strikingly low. It is an impact akin to that of mobility policies more generally, such as the Erasmus and Socrates education schemes: a slow moving change, that actually touches a lot of people.

The actual modes of participation of European citizens in these three cities should thus lead us to doubt the party political fixation about representation and the democratic deficit that dominates academic and media debates. The kinds of rights embodied in European citizenship are much better translated into the choices and actions of consumers, tourists, students, and cross-border workers, than into crosses in ballot boxes. National politicians disgraced themselves in June 2004 and 2009 by hardly talking about Europe or the EU (and what it actually does) in the European elections. They turn these elections into plebiscites about nationally specific issues, and nationally specific political cleavages. They 
have played cavalier nationalist games with the European constitution and its ratification in 2005, or various European referenda, attempting (successfully) to hijack European policy issues by putting them at the mercy of Eurosceptic national voters. As a result, politically speaking, the EU has taken several steps backwards in recent years. What gets pointed to as democratic deficit, then, is largely a symptom of the grip of Europe's highly nationalised past and the dominance of national concerns on European politics (Schmidt 2008). The biggest threat to the EU is in fact the bankruptcy of European national politics, and the increasing equation of democracy with populist mass plebiscites - such as referenda and US presidential style elections. Looking again at the face of such "democracy", and we might conclude that these forms of participation are more appropriate to the authoritarian politics of the European past, than the multi-levelled, multi-scalar governance that might (still) be Europe's future.

On one reading, the evidence presented here underlines that mobile European citizens are often not very politically participative in the localities they live in, and that their modes of practicing European citizenship appear, if anything, to be rather apolitical. But since so much more can be said about their active engagement as residents, consumers, parents, and gentrifiers in the cities they have chosen to live in, this suggests that our conventional models of political participation may be missing much of the story. If we wish to look to these "Eurostars" as prototypical political participants in the future Europe being built, then it is to other modes of participation that we should turn-a broader range of interactions with their host society that reveal distinctive modes of integration for free moving Europeans in Eurocities.

\section{A local politician's tale}

Rik Jellema is something of a local legend in Brussels. A Dutch political activist and cycle fanatic, married to a French woman, he has become one of the very few successful foreign European politicians on the local communal level political scene, not least because he has always managed to transcend and combine Francophone and Dutch speaking interests in his fervent green-left politics. Despite a steady rise to prominence over a ten year period, he has in 2009 found a ceiling to his involvement. Wanting to move up to the much more politically significant 
regional level representation in Belgium (the Brussels-Region-Capital), he had his petition for Belgian citizenship - necessary, in this case, as EU voting rights are limited to the commune level - turned down because he is an employee of the European institutions in Brussels - a translator, in fact. Characteristically, Rik has turned this into a live campaigning point in his political activities.

I meet up with him in the foyer of the Council Building, on rue de la Loi. They are nervous here about people carrying tape recorders, so he whisks me out of the building. We head over to a local café in the shadow of the Berlaymont building for lunch. In the pale winter sunshine, the recently refurbished building is looking a lot better than it once did. Parts of the neighbourhood, though, still look like a building site. Rik is a quite unique character on the Brussels scene who has no sympathy for many of the archetypal Eurocrat attitudes, and couldn't be further from the stereotype himself. Being a politician, he also knows how to give a great interview.

I came here in '87. I was almost 30 years old, and I had a wife from Paris. For us, it was just "in between". It was one of the reasons I wanted to go to Brussels. I wanted to go abroad, not especially to work for the EU, but being a translator of course, it's a very good job. We wanted to get closer to France, and I wanted to leave Holland because I was a little bit fed up with the way of living there. I wanted a change. I had been living 11 years in Groningen, but this [Brussels] is really my home town now.

My wife does not at all work in a Euro type job. She has a small shop, selling toys - wooden toys and clothes for small kids. It's in front of a maternité- not a crèche, the place where children get born. She is not at all into this European stuff. She even hates it, I'd say, the European circles, the people you are used to meeting there. She is completely out of this. It's maybe another reason for my "integration" here. We decided to send our children, who were born here in Brussels, to Belgian schools, not the European schools. It's where you meet people, make friends. They've been through both systems: first kindergarten in a Flemish school, now the French speaking school. You know the two systems in two languages, so we met parents on both sides of what we always call "la frontière linguistique" [laughs]. My kids are 11 and almost 14. I think my wife was pregnant when we came here. The first was born in the first year I worked here. It was the same year I lost my parents both my parents - so, it was a kind the end of an old book. I closed the book, the chapter in Holland, and decided to concentrate on living here entirely in Brussels. I had no family left, only one brother...

My wife was living with me seven years in Holland, and she didn't want to quit. She was rather sad to leave, in fact, but now she's happy in Brussels. 
She was well integrated, spoke Dutch very good. But I wouldn't mind going to France, it's a home country as well. I think it's true, the idea of a "third country" being a neutral space for couple like us... It's one of the keys of success in integration. If both partners want to go. I see a lot of colleagues whose wives have nothing to do... playing tennis, the expat syndrome. It's no good. She had a good job in Holland. She came here without a job, so what she is doing has been very important. It's $O K$, if you both decide to go to the third country to make a new living. Not having the idea that it's just for one or two years... We are here, you have to make the best of it.

That is one of the problems of expats. They continue of having this dream of going back, of returning home. For example, there are European civil servants who live in Overrijse [a typical affluent expat suburb] for 20 years now, and they never learn Dutch. It's a real ghetto... well, ghettos. Even before coming here they know where to go to, the English there, the Dutch there, the Germans there. They think they are only here for a few years, but after retirement, they decide to stay. It can be 20 or 30 years or longer, and they never really do it... Most of the children go back home, for university. That's in a "home" where they were not even born! A lot of children from the European civil servants go to university abroad like that. They've been to the European school, and they don't know the Belgian system. They have a very bad image of the Belgian system.

It's also their perception of Belgians, as foreign people. Yes, it's not easy to have a close relation with the locals. The family structure is very important, it's not that easy. The only way to get integrated is through association life. Not necessarily a club. You have to get engaged in local life. People don't talk to each other in the street, your contact with neighbours is rather superficial, It's just "bonjour, bonsoir". So, if you want to get integrated, you have to join a local association, get active. Age is an important element in the process. If you are too old when you come here, don't have the energy... It's a social phenomena. It's also that the Europeans earn a lot of money. They are a kind of caste, in the higher spheres of society, because they earn a lot of money. It's one of the problems with integration. It creates jealousy with the Brussels people.

A lot of people are unhappy here. I have colleagues who are always complaining. They are complaining about everything: the weather, the post offices, the policemen, the car congestion. They're not happy, they're really not happy. So money doesn't make you happy. [Ironically] This is a consolation for me, being a Calvinist. They have discovered that there is something that doesn't make you happy, it's money.

I ask him about his involvement in local politics. In this respect, Rik is the consummate Brussels political actor, a Brusselaar playing on all sides at once. 
I was involved already at the first election, but I had no voting rights then. I was just what they call a "basic militant", distributing tracts and things like that, in Etterbeek. I was in the local section. I did work for Ecolo [the francophone green party], so they knew me already. I was not a complete foreigner to them. I'd already had this engagement. I was not really active in either [Ecolo, or Agalev, the Dutch speaking greens]. I qualify myself as an "independent", but if you want to go into politics, you need a political structure. You better have a member card, and try to get involved in the party structure. I'm not that active in Agalev. My contacts are more with Ecolo, as I told you. It's mostly French speaking, it's why I decided to join them. I was a member of both, but I'm more active in the local structure of Ecolo. It's no problem for me, it's no problem for the party (the fact he is Dutch). We have a very good cooperation.

Are you listed as a Dutch speaker in the electoral list?

Yeah, I was. Well, actually, no. It was a French speaking list Ecolo, with five Dutch speaking persons on it, who were Agalev or independent. But it was clear to the voters that I was Dutch speaking. I didn't make a point of this. Well, to some voters, I made a point of this - to Dutch speakers - to others I just said I'm Green. Your profile depends on what people find most important. I don't see language as a barrier, or as an obstacle. It's a way of communicating. I mean, I'm a translator. I know what language is. It's really important to communicate. If it has to be in French, it's in French. If it has to be in Dutch, it's Dutch.

How did he first get involved?

It was the cycling lobby. When I came here, I left my bicycles in Holland, because everyone said, "You can't cycle in Brussels". They were right... You can't! It's a disaster. So the first year, I walked. It was like cold turkey. I needed my bicycles. So I bought a bicycle, 12 years ago. There were so few cyclists that everyone who was a cyclist was a kind of militant. I was kind of a hard one. I met these people... Being a Dutch speaker, the circle of Dutch speakers is not so big in Brussels. [Laughs] So the circle of Dutch speaking cyclists is even smaller. Before I knew that, there was a lobbying group, de Fietsebond. Le Grak is the French speaking side - of course, there are always two - and I became rather engaged in this movement. I was even president for four years. I went to a lot to ministerial cabinet meeting, I had contacts with politicians. I kind of liked it, having the impression that you can change society. Maybe not society as a whole, but a little part of it. People started to know me, you know, through TV Brussel [the local Dutch speaking TV station] and all 
that. I was interviewed several times.. I became a Brusselaar, on a real small scale. In the Dutch speaking community, a lot of people started to know me. I think Agalev also had the idea of making benefit from this - the fact that people knew me, and had seen me on television. But it was always about cycling. I've done this, I've been rather engaged for ten years, and I wanted to do something more broad. There is this mobility problem that is rather big in Brussels compared to other cities. Cycling is only part of the mobility problem. And living in the city, mobility is only part of that, part of the broader quality of life issues. So that's why I decided to go into politics. You start by trying to change things in your own commune. The municipal elections is the level that is most close to the people, and I've always lived in Etterbeek since I came to Brussels, so I know a lot of people...

I live up near Avenue Auderghem and de Chasse. There are no Eurocrats there. Just lot of old Belgian people, Brussels working class and petit bourgeoisie. It's real Brussels. Nothing special, just small shops, bars, etc. The Dutch speaking community is organised at the regional level, in the communes it's too small for association. Etterbeek is not particularly Dutch. There might be $10-12 \%$ of the electorate, but they are dispersed. There's the gemeentecentrum. The Dutch speakers go there to meet each other. That's an advantage of the smallness of the Dutch speaking community in Brussels.

What about the quite high number of European residents in Etterbeek? Have they played a role?

No, I don't think so. It's 7\%. It didn't play a role. I sent them a letter, but everyone did. The burgomeester, the alderman, every party tried to target them. But all I did was compare the list offoreign electors with European civil servants. I tried to find my colleagues in the institutions, and I wrote to them to say that I was a fellow foreigner and a colleague. That's the only thing I did, it was maybe 180 letters. I know that the burgomeester sent a letter to all the foreigners. He has access to the electronic files. I had to do it all by hand, just compare the lists.

I didn't present myself as a candidate of the Eurocrats, or of the Dutch speakers. I consider myself to be an "Etterbeekois parmi les Etterbeekois", and I think this is the way that people perceived me. There was never a question or remark about me being a Dutchman. You know in fact being a Dutchman is a rather a handicap with Flemish people. You are a "Hollander", you know, and that's an insult! And being a Eurocrat is also a handicap. So I have a double handicap! Well, they considered me an Etterbeekois. There were never any allegations or fun making. Only my colleagues [at work] made fun of me. 
Did anyone come to you as a representative, to ask for something as a European?

No... Well, since I've been elected people come to me. You know, 'Vous pouvez pas arranger quelquechose pour moi?', 'Do you know somebody? Can you phone somebody? Fix this for me?". If they have a problem, they come to you. This proves that you are very close to the people. There is a communication problem between the population and the commune, so they see you as a kind of go-through [go-between]. They ask you for information, how they have to go through something. Even if the commune is rather close to the people, there is still a kind of threshold, So they know you and they come to you and they ask to solve their problem. It's not corruption, this is just how it works here.

But why did the attempts to mobilise the European population as voters not work?

[Laughing] The official campaign to get people to register was late and not very convincing. So I think next time they'd better send a letter to everyone and ask people to get the form. They need to simplify the procedures. A lot of people thought they would have to be obliged for the rest of their life to vote [voting in Belgium is legally obligatory if you are registered]. It's not the case. If you don't want to vote next time, you can ask to get off the list. But the procedure is too heavy.

But really, the mentality of the people [the European residents] is not really interested in what is happening in Brussels. It's all too complicated for them. At the national level, it's complicated. But at the level of the commune, it's not really that complicated. It's about real issues, rather simple issues, like clean streets, security, too many cars, parking, cars driving too fast. I can't understand this kind of disdain you hear about this country. Like it's a "banana republic" or "ape country". A lot of my colleagues think it's a kind of silly country, with all this linguistic stuff. They don't understand...

The really big contrast is with the "ethnic minority" participation in Brussels politics, beginning in 2000, when the "ethnic vote" was very successful at the local level.

Yeah, it did play a role. On our list, there were several Moroccans. They were not listed in the highest positions, but they all got elected from lower positions. We are eight elected now. There was one guy from Iran, this was definitely the ethnic vote, plus two from a lower position who got elected. And there was a real Flemish guy, who was bottom of the list, who also got elected. 
So there is a kind of ethnic vote going on. My election was largely because I was third on the list, and we got eight seats. The list did better than we expected. We went from two to eight seats, this was a result. Out of eight seats, there are four foreigners. There was also an English woman elected, and a French woman, but that wasn't the ethnic vote.

Ethnic minorities are 20\% of the vote [in Etterbeek]. The system is that of the preferential vote. It's rather complicated. You can have 33 names on the list, and if the 32nd one gets elected, that's the effect of the preferential vote. It played a role with the Moroccan vote in all communes. It is a problem if a lot of these people are not prepared [for office]. I think it's a big responsibility to get them prepared in the next six years. It was such a surprise when they got elected [in 2000]. They had the spirit, but they were not well enough equipped maybe. It is bad, though, when 30\% of the people in this city [the ethnic minority population] have no influence. They are over $50 \%$ in some communes, it's a real issue. So this has changed the political landscape. On the other hand, there is the problem that maybe next time the ethnic vote will not have the same influence, because voters will be disappointed.

I ask him about the Brussels' language struggle. The Dutch in Brussels sometimes get involuntarily dragged into it.

You are, yeah. Sometimes you have to choose sides, even if you don't want to. The problem with Dutch speakers here is that the moment they hear you are a foreigner they start speaking English to you... But I'm in the Friesian speaking minority [in the Netherlands], from Leeuwarden. I mean. I understand the position of the minority. This might be one of the reasons I'm well integrated here.

It's luxury to be a minority in a way. As a Dutch speaker here, there are always places you know you can go. Their profile is quite specific. The Flemish in Brussels are either the real old Brusselaars, or the hip young cosmopolitan incomers getting away from the nationalism and xenophobia in Flanders...

Yeah. In Etterbeek, it's the old people. It's not like the scene in Dansaertstraat [the hipster Sint Kathelijne neighbourhood]. The success of Agalev in Brussels city is due to the phenomenon of gentrification. You've heard about Bruno de Lille, I suppose [a local Dutch speaking Green politician who became alderman of Brussels-Centre after mobilizing foreign voting votes in his favour]. It's quite interesting how he got elected. He came to Brussels maybe two or three years ago. I don't think he knows much about Brussels apart from the vijfhoekje, the pentagon [the inner ring 
of Brussels]. But [the Flemish in the centre] has proven to be a sufficient base for him to get elected. It's quite a surprise. Now, he's the Schepen [the Alderman]. In Etterbeek, this wouldn't be possible. It's a different population. And the funny thing is, these young people, they don't see the French speaking as the enemy. The FDF, is the Flamophobic party to a lot of older Flemish speaking people. It's the enemy, the devil. They'd never go to someone who is on the list with the FDF. But, for the young Flemish people, the FDF is just a party from the past. It's true. When you speak with them the older people, they always start talking about the past. It's not that long ago. Relations in Etterbeek were really bad fifteen, twenty years ago, between the French and Dutch speaking. Now, there's a kind of pacification there of the linguistic community issue. The relations are rather good.

How do these issues play out at the family level?

My children, they are French and Dutch. They have the double nationality, and they could be Belgian too at the age of 18 because they were born here. But strangely enough, all the time in Belgium, they don't feel really Belgian. My youngest, who is 11, he said, "j'aimerais pas être belge". I say, "Huh? Why not?”. “Je sais pas. J'aimerais pas". They just know they are not [Belgian], even if they are born here... I regret that my children are more... [hesitating]... are better French speaking than Dutch speaking. This is part of the education that failed. We applied the "Brussels model". Everyone speaks his own language, and understands the others' language. I speak Dutch to my children, but they answer in French. Their language at school, in the street, is French. I am alone at home to continue the fight. But I'm a Friesian, so I'm stubborn and I continue. But it's a frustration for me. When I compare them to children of their same age in Holland, their Dutch is rather weak. They have a good passive knowledge, but they prefer to speak in French. I speak French to my wife, so why should they speak Dutch to me? In the beginning they did, but slowly French took the dominant position like everywhere in Brussels. So if there's one thing I regret, being a translator, it's this language question.

So what is the future of Brussels? Everything depends on its place in the Belgian context, continuing the precarious balance between the communities.

As long as the Walloons need Flemish money, Brussels will exist like it is now. If there hadn't been Brussels, we would have had here the Czech-Slovak construction. They would have split up. But Brussels is still the capital of a bi-lingual country and no-one wants to give up Brussels. As long as the Flemish want to keep Brussels, and the Walloons need the money, for example, for the education system. 
Why not make it a neutral international city, as people like the public philosopher Philippe van Parijs has suggested? Brussels DC.

This would be an insult. As if to say to small children, you are not capable of governing your own capital. We'll do it for you. But you see what Europe does to this part of the city? [gesturing to the ugly buildings outside] I don't think we'll be much better off with a European district. You have to understand that the Brussels Region is rather young. It was only created in 1991, and a lot of things have improved. It's powers are increasing. The Flemish don't like it. They are not keen about this three tier system, the two regions plus Brussels, the Brussels-Region-Capital. But its still not a full region with its own independent powers. In the Belgian structure, it is rather fragile. It's rather weak. It's not easy, because it's a play toy for the national politicians. They project their ideas about Belgium on Brussels. For example, there is this thing going on now with the extension of the European buildings in Ixelles. Or Brussels as a conference centre. Guy Verhoftstadt [the former Belgian prime minister] had this brilliant idea of putting it here right in the heart of Etterbeek, and Etterbeek wasn't even consulted. That's Belgian politics.

It's a problem between the communes and the region. The communes are too strong, and the region too weak. The region should have more powers. The communes are the administrative level, but everything to do mobility, or infrastructure should be at the level of region. And you find the same guys, all the burgomeesters of the communes at the Region, and so the Region is only a guichet. They just by-pass the level, and go from federal level to the communes. They prefer not to decide things at that level [of the Region]. But it's still young. The commune is too small a level, I'd prefer to be active at the regional level. But we [as foreign European residents] still have no voting rights at the level of the region. I'm a nieuwe Brusselaar, so I believe in the Brussels region. If a bi-lingual region in the centre of Europe is impossible, Europe is impossible. For me this is the real idea of what Europe should be. Different communities, different languages, different cultures, living together in one region. For me, if this is impossible, forget everything about Europe being a multicultural society. So Brussels should be possible, but we have to work on it. I believe in it.

As we finish, we fumble with splitting the bill.

I'm a Dutchman. I can't count. 


\section{REFERENCES}

Andreotti, Alberta and Le Galès, Patrick (2010). "Elites, middle classes and cities", in Adrian Favell and Virginie Guiraudon (eds.), The Sociology of European Union. London: Palgrave, forthcoming.

Angell, Ian (2001). The New Barbarian Manifesto: How To Survive the Information Age. London: Kogan Page.

Beck, Ulrich and Grande, Edgar (2004). Kosmopolitisches Europa. Frankfurt/Main: Suhrkamp Verlag.

Bellamy, Richard and Castiglione, Dario (eds.) (2006). Making European Citizens: Civic Inclusion in a Transnational Context. London: Palgrave Macmillan.

Berezin, Mabel and Díez Medrano, Juan (2008). "Distance matters: place, political legitimacy, and popular support for European integration", Comparative European Politics, 6: 1-32.

Bourdieu, Pierre et al. (1993). La misère du monde. Paris: Seuil.

Bousetta, Hassan and Swyngedouw, Marc (1999). "La citoyenneté de l'Union européenne et l'enjeu de Bruxelles”, CRISP. Courier Hebdomadaire, 1636.

Bréchon, Pierre and Cautrès, Bruno (eds.)(1997). Les enquêtes eurobaromètres: analyse comparée des données socio-politiques. Paris: L'Hartmattan.

Brubaker, Rogers and Cooper, Frederick (2000). "Beyond identity", Theory and Society 29, 1: 1-47.

Bruter, Michael (2005). Citizens of Europe? The Emergence of a Mass European Identity. Basingstoke: Palgrave.

Butler, Tim and Robson, Garry (2003). London Calling: The Middle Classes and the Remaking of Inner London. Oxford: Berg.

Checkel, Jeffrey and Katzenstein, Peter (eds.) (2009). European Identity. Cambridge: Cambridge University Press.

Citrin, Jack and Sides, John (2004). "More than nationals: How identity choice matters in the new Europe", in Richard K. Herrmann, Thomas Risse, and Marilyn Brewer (eds.), Transnational Identities: Becoming European in the $E U$. Lanham, MD: Rowman and Littlefield, 161-185.

Díez Medrano, Juan (2003). Framing Europe: Attitudes to European Integration in Germany, Spain and the United Kingdom. Princeton, NJ: Princeton University Press.

Deutsch, Karl W. et al. (1957). Political Community in the North-Atlantic Area: International Organization in the Light of Historical Experience. Princeton, NJ: Princeton University Press.

Duchesne, Sophie and Frognier, André-Paul (2002). "Sur les dynamiques sociologiques et politiques de l'identification à l'Europe", Revue française de science politique, 52, 4. 
Eriksen, Erik O. (ed.) (2005). Making The European Polity: Reflexive Integration in the EU. London: Routledge.

Favell, Adrian (2005). “Europe's identity problem”. West European Politics, 28, 5: 1109-1116.

Favell, Adrian (2008). Eurostars and Eurocities: Free Movement and Mobility in an Integrating Europe. Oxford: Blackwell.

Fligstein, Neil (2008). Euroclash: The EU, European Identity, and the Future of Europe. Oxford: Oxford University Press.

Forêt, François (2008). Légitimer l'Europe. Paris: PFNSP.

Gabel, Matthew (1998). Interests and Integration: Market Liberalization, Public Opinion, and European Union. Ann Arbor: University of Michigan Press.

Green, David M. (2007). The Europeans: Political Identity in an Emerging Polity. Boulder, CO: Lynne Rienner.

Habermas, Jürgen (1992). "Citizenship and national identity: some reflections on the future of Europe", Praxis International, 12, 1: 1-19.

Herrmann, Richard K., Risse, Thomas and Brewer, Marilyn (eds.) (2004). Transnational Identities: Becoming European in the EU. Lanham, MD: Rowman and Littlefield.

Kaelble, Hartmut (1987). Auf dem Weg zu einer europeischen Gesellschaft. Munich: Beck.

Jacobs, Dirk (2000). "Multinational and polyethnic politics entwined: minority representation in the region of Brussels-Capital". Journal of Ethnic and Migration Studies, 26, 2: 289-304.

Magnette, Paul (1999). La citoyenneté européenne. Bruxelles: Éditions de l'Université de Bruxelles.

Maas, Willem (2007). Making European Citizens. Lanham, MD: Rowman and Littlefeld.

Mann, Michael (1993). The Sources of Social Power: Vol 2. The Rise of Classes and Nation-States 1760-1914. Cambridge: Cambridge University Press.

Meehan, Elizabeth. 1993. Citizenship and the European Community. London, Sage.

Moravcsik, Andrew (2002). "In Defense of the 'Democratic Deficit': Reassessing the legitimacy of the European Union", Journal of Common Market Studies, $40,4$.

Muxel, Anne (2009). "EU movers and politics: towards a fully-fledged European citizenship?", in Ettore Recchi and Adrian Favell (eds.), Pioneers of European Integration: Citizenship and Mobility in the EU. Cheltenham: Edward Elgar, 156-178.

Recchi, Ettore and Favell, Adrian (eds.) (2009) Pioneers of European Integration: Citizenship and Mobility in the EU. Cheltenham: Edward Elgar. 
Risse, Thomas ((2004). "European institutions and identity change: What have we learned?", in Richard K. Herrmann,Thomas Risse, and Marilyn Brewer (eds.), Transnational Identities: Becoming European in the EU. Lanham, MD: Rowman and Littlefield, 247-271.

Rodríguez-Pose, Andrès (2002). The European Union: Economy, Society, and Polity. Oxford: Oxford University Press.

Rother, Nina and Nebe, Tina (2009). "More mobile, more European? Free movement and EU identity", in Ettore Recchi and Adrian Favell (eds.), Pioneers of European Integration: Citizenship and Mobility in the EU. Cheltenham: Edward Elgar, 120-155.

Savage, Mike, Bagnall, Gaynor, and Longhurst, Brian (2005). Globalization and Belonging. London: Sage.

Scharpf, Fritz (1999). Governing in Europe. Oxford: Oxford University Press. Schmidt, Vivien (2008). Democracy in Europe. Oxford: Oxford University Press. Siedentop, Larry (2000). Democracy in Europe. Oxford: Oxford University Press. Shaw, Jo (2007). The Transformation of Citizenship in the European Union: Electoral Rights and the Restructuting of Political Space. Cambridge: Cambridge University Press.

Shore, Cris (2000). Building Europe: The Cultural Politics of European Integration. London: Routledge.

Strudel, Sylvie (2002). "Les citoyens européennes aux urnes: les usages ambigues de l'article 8B du traité de Maastricht", Revue internationale de politique comparée, 9, 1:47-63.

Strudel, Sylvie (2003). "Polyrythmie européenne : le droit de suffrage municipal des étrangers au sein de l'Union : une règle électorale entre détournements et retardements", Revue française de science politique, 53, 1.

Therborn, Göran (1995). European Modernity and Beyond: The Trajectory of European Societies, 1945-2000. Thousand Oaks: Sage.

Weiler, Joseph (1998). The Constitution of Europe. Cambridge: Cambridge University Press.

Wiener, Antje (1998). European' Citizenship Practice: Building Institutions of a Non-State. Boulder, CO: Westview Press. 